\title{
The Effect of Premature Births on Language Delay in Children: A Meta-Analysis
}

\author{
Alfiani Vivi Sutanto'), Didik Gunawan Tamtomo²), Bhisma Murti1) \\ ${ }^{1)}$ Masters Program in Public Health, Universitas Sebelas Maret \\ ${ }^{2)}$ Faculty of Medicine, Universitas Sebelas Maret
}

\section{ABSTRACT}

Background: Child development problems are problems that need attention. A child can experience developmental delays in one or more developmental domains. It usually occurs in infants who born prematurely. In Indonesia, data from the Ministry of Health states that there are 675,700 premature infants in Indonesia. This study aimed to examine the effect of premature births on language delay in children using a meta-analysis

Subjects and Method: This was a systematic review and meta-analysis. The articles used in this study were obtained from several databases including PubMed, Wiley, Springer Link, Elsevier, BMC Pediatrics and Google Scholar. The articles used in this study were those published from 2000-2020. The article search was carried out by considering the eligibility criteria defined using the PICO model. The population in the study were children with intervention in the form of babies born prematurely, the comparison was that babies born at term, the outcome was language delay. The keywords for searching articles are as follows: (preterm OR "short gestational ages" OR SGA OR prema- ture) AND "language delay" AND child AND observational AND aOR. The articles included in this study are full text articles with an observational study design. Articles were collected using PRISMA flow diagrams. Articles were analyzed using the Review Manager 5.3.

Results: A total of 8 articles from the Americas, Europe, Asia and Australia were reviewed in this study. The meta-analysis combining 8 cohort studies concluded that preterm infants caused language delay in children 1.65 times as much as non-nomal children $(\mathrm{aOR}=1.65,95 \%$ $\mathrm{CI}=1.11$ to $2.44, \mathrm{p}=0.010$ ).

Conclusion: Infants born prematurely experience delays in language development.

Keywords: premature birth, language development delay

\section{Correspondence:}

Alfiani Vivi Sutanto. Masters Program in Public Health, Universitas Sebelas Maret. Jl. Ir. Sutami 36A, Surakarta 57126, Central Java. Email: alfianivivi85@gmail.com. Mobile: 085799253568.

Cite this as:

Sutanto AV, Tamtomo DG, Murti B (2021). The Effect of Premature Births on Language Delay in Children: A Meta-Analysis. J Matern Child Health. 06(01): 67-76. https://doi.org/10.26911/thejmch.2021.06.01.07.

(c) (1) Journal of Maternal and Child Health is licensed under a Creative Commons Attribution-NonCommercial-ShareAlike 4.0 International License.

\section{BACKGROUND}

Child development problems are problems that need attention. A child can experience developmental delays in one or more developmental domains. This developmental delay problem usually occurs in children born prematurely. This is because the level of development of premature babies in the first year is generally lower than babies who are born at term on the same day (Putri et al, 2018).

Premature birth occurs when the baby is born at the mother's gestation at less than 37 weeks. A child is considered to have speech and language delays if the development of speech and language is significantly below the milestones of his age (Patterson, 2017). Delays in premature development usually include motor development, social 
adaptation, and language (Eisenberg, 2002).

Nearly one million children die each year from complications of preterm birth, with more than $60 \%$ of preterm births occurring in Africa and South Asia. Meanwhile, in low-income countries, an average of $12 \%$ of infants was born prematurely, while in high-income countries only $9 \%$ (WHO, 2014). Ministry of Health data shows that there are approximately 675,700 premature babies in Indonesia (Mariyana, 2018). Taylor et al (2018) stated that there are $67 \%$ of babies born prematurely with language disorders occurring in Western Australia. Meanwhile, in Mongolia, 11.7\% of babies born prematurely are at risk of experiencing language disorders (Dagvadorj et al., 2018).

The number of primary studies examining the effect of preterm infants on language delay in children has prompted researchers to conduct a more comprehensive study of these primary studies. The data obtained will be analyzed using a systematic review and meta-analysis by synthesizing the results of studies conducted to reduce bias.

\section{SUBJECTS AND METHOD}

\section{Study Design}

This was a systematic review and meta-analysis. The articles used in this study were obtained from several databases including PubMed, Wiley, Springer Link, Elsevier, BMC Pediatrics and Google Scholar. The keywords for searching articles are as follows: (preterm OR "short gestational ages" OR SGA OR premature) AND "language delay" AND children AND observational AND aOR.

\section{Inclusion Criteria}

The articles included in this study were full paper articles with an observational study design and English. Appropriate articles should mention preterm infant interventions with language delay outcomes.

The articles are those that use the appropriate population, namely children. The analysis used is the multivariate adjusted Odds Ratio.

\section{Exclusion Criteria}

The articles published in this study are articles that have been carried out by metaanalysis. The articles are published before 2000 and are not multivariate articles.

\section{Operational Definition}

The article search was carried out by considering the eligibility criteria defined using the PICO model. The population was children. The intervention was premature infants with comparison was aterm birth infants. The outcome was language delay.

Language delay is language development that is significantly below the milestone of a child of his age (Patterson and Dale, 2017).

Gestational age is one of the things that can affect fetal survival and quality of life. Generally, pregnancy is termed term if it lasts between 37-41 weeks counting from the first day of the last menstrual cycle on the 28 day cycle. Meanwhile, labor that occurs before the gestational age reaches 37 weeks is called preterm labor (Widjayanegara, 2009 in Sulistiarini, 2013).

Mariyana (2018) in analyzing the relationship between the incidence of prematurity and development shows that there are differences in the incidence of developmental delay in prematurity. This is in line with research conducted by Soubasiet al (2014) which states that children who are born prematurely experience neurological delays and low cognitive levels. According to Raybaud et al (2013), brain development in children born prematurely is often unstable. 
Sutanto et al./ The Effect of Premature Births on Language Delay in Children

\section{Data Analysis}

Data processing was performed using the Review Manager (RevMan 5.3) by calculating the effect size and heterogeneity to determine which research models were combined and formed the final metaanalysis result.

\section{RESULTS}

The process of searching for articles by searching through a database with journals can be seen in Figure 1. Figure 2 shows the areas where articles were taken according to the inclusion criteria. Articles obtained from 4 continents, namely Asia, America, Europe and Australia.

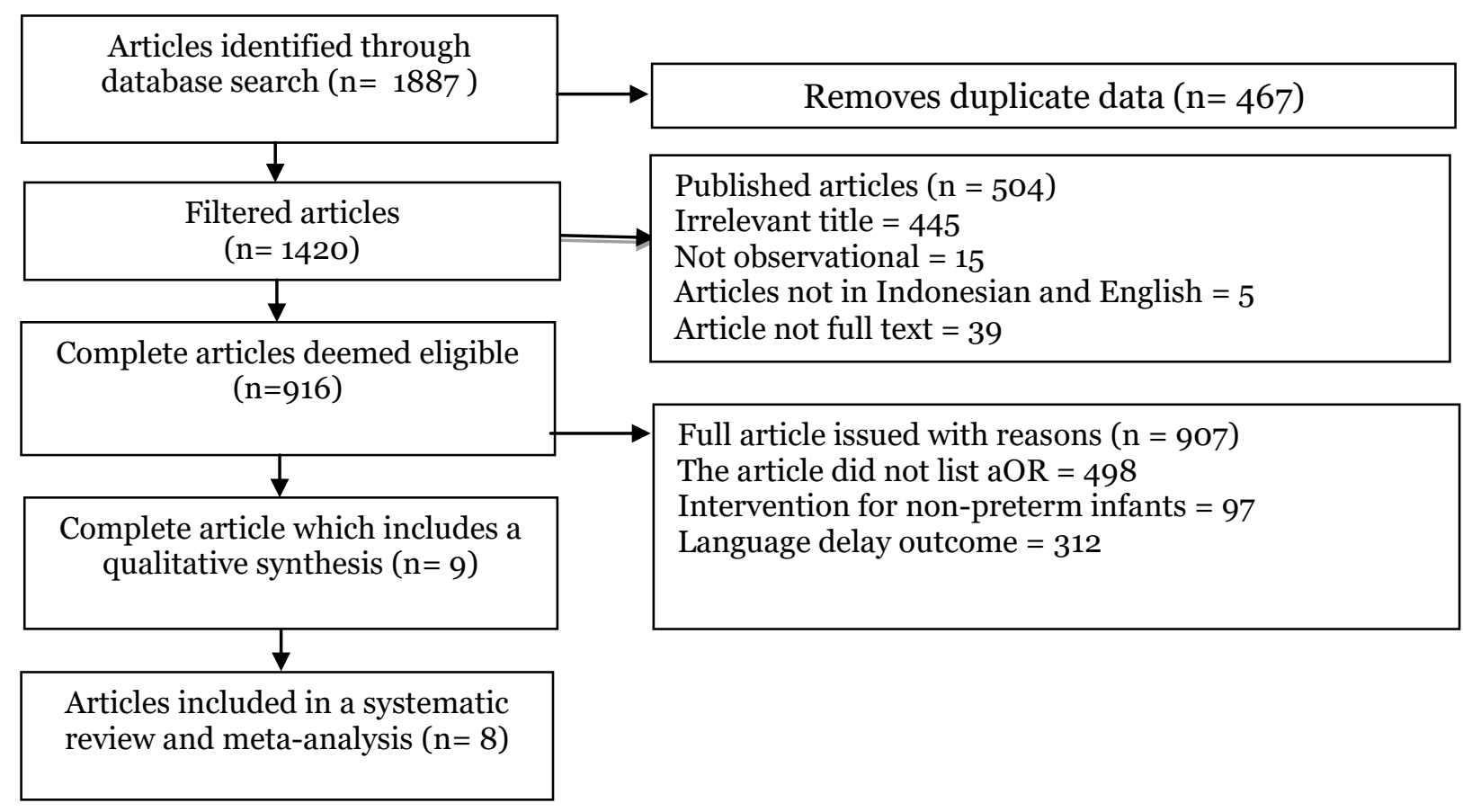

Figure 1. PRISMA diagram

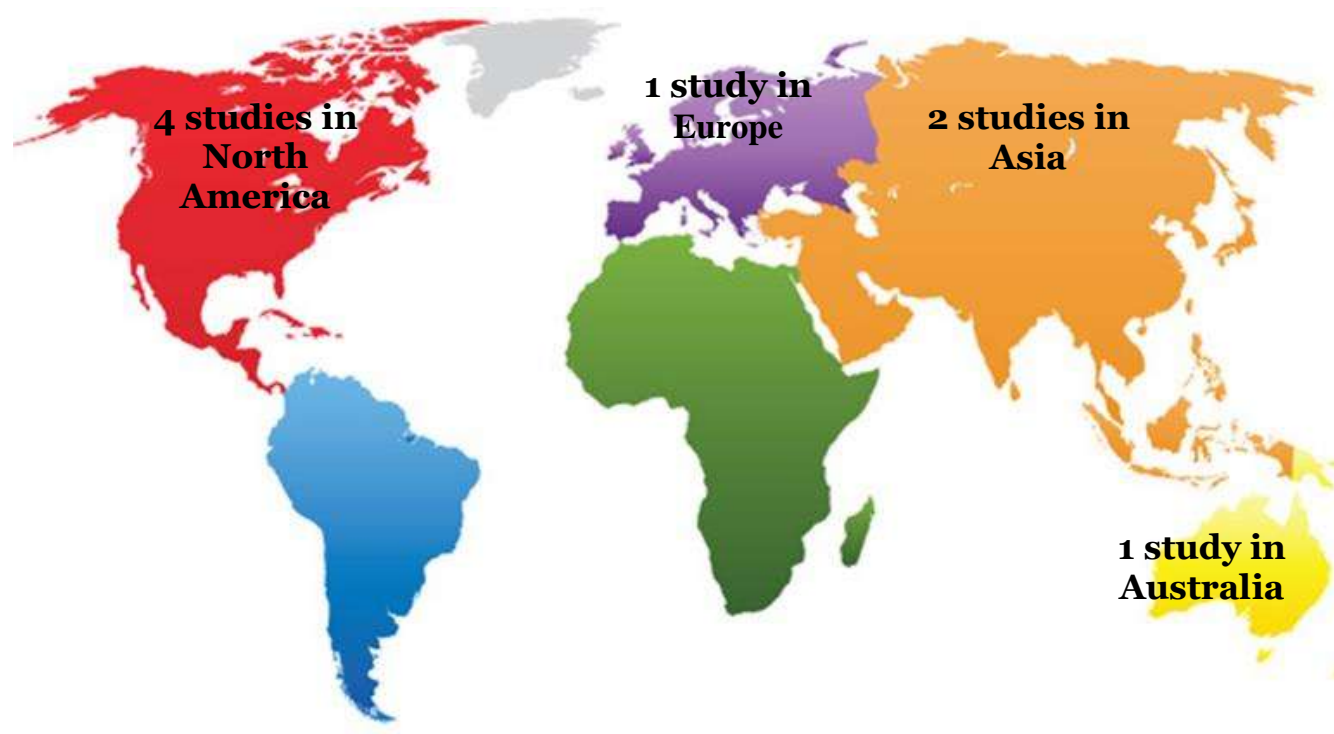

Figure 2. Research area 
Sutanto et al./ The Effect of Premature Births on Language Delay in Children

Based on the results of the forest plot (Figure 3) in the cohort study, preterm babies could cause language delay in children 1.65 times compared to children who were born nominally which was statistically significant $(\mathrm{p}=0.010)$. The heterogeneity of the research data shows $\mathrm{I}^{2}=85 \%$. So that the distribution of the data is heterogeneous (random effect model). The funnel plot (Figure 4) is characterized by asymmetry of the right and left plots where 3 plots are on the left, 4 plots are on the right and 1 plot is in the middle. The plot on the left of the graph appears to have a standard error between 0 and 1 and the plot on the right has a standard error between 0.2 and 20.

\section{a. Funnel plot}

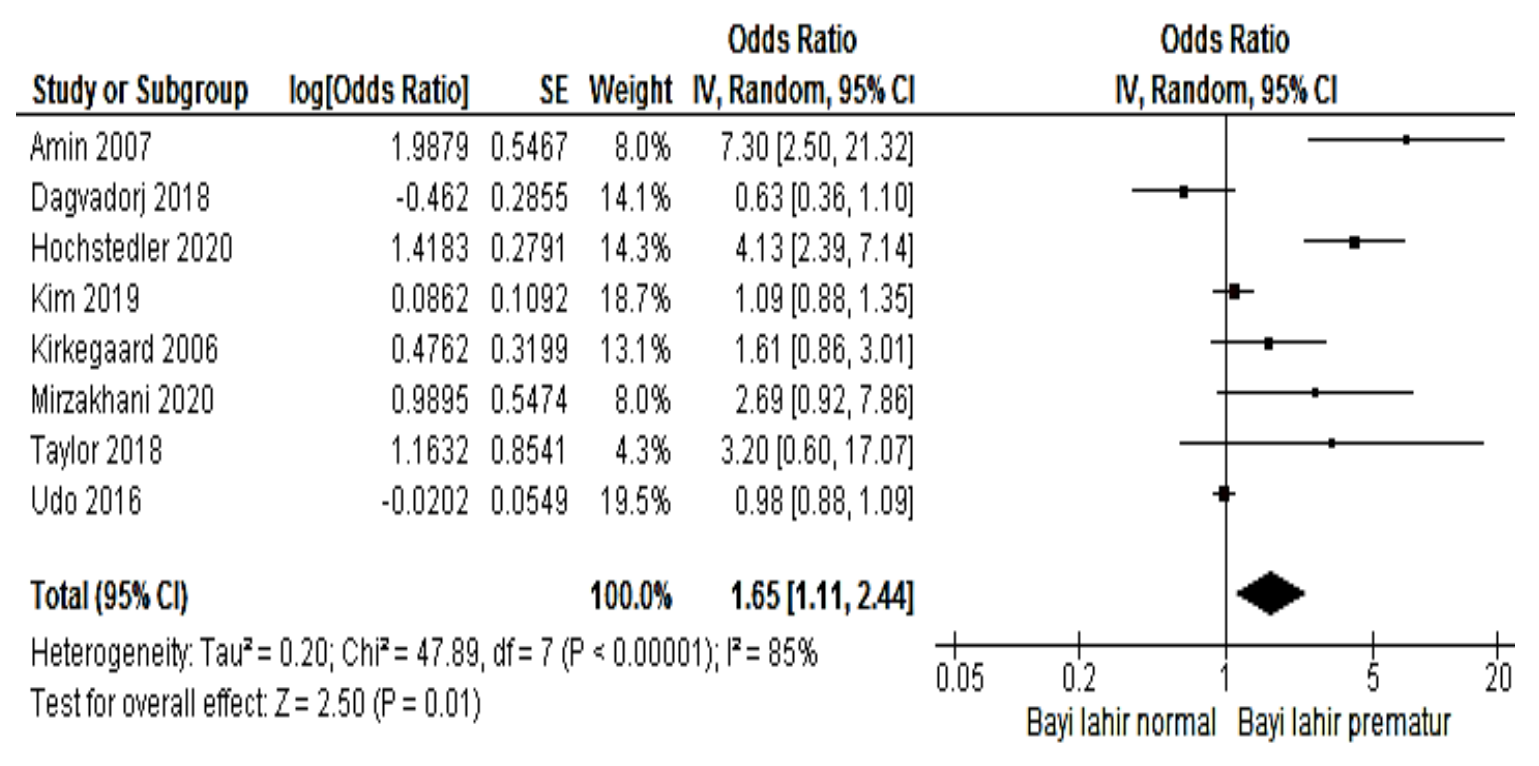

Figure 3. Funnel Plot of Influence of Premature Birth on Language Delay in Children

\section{b. Forest plot}

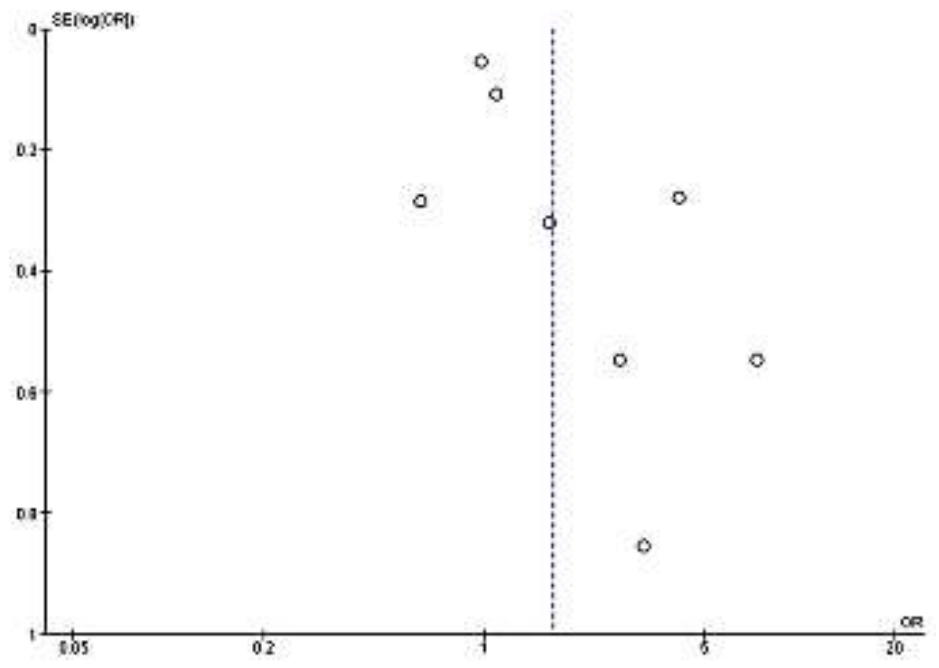

Figure 4. Funnel Plot of Influence of Premature Birth on Language Delay in Children 


\section{Table 1. Critical Appraisal Skills Programme (CASP) for Cohort Study}

\begin{tabular}{|c|c|c|c|c|c|c|c|c|}
\hline \multirow[b]{3}{*}{ Questions in the checklist } & \multicolumn{8}{|c|}{ Publication } \\
\hline & \multicolumn{8}{|c|}{ (Author and year) } \\
\hline & $\begin{array}{c}\text { Kirkegaard } \\
\text { et al. } \\
(2006)\end{array}$ & $\begin{array}{c}\text { Amin } \\
\text { et al. } \\
(2007)\end{array}$ & $\begin{array}{c}\text { Udo } \\
\text { et al. } \\
\text { (2016) }\end{array}$ & $\begin{array}{c}\text { Taylor } \\
\text { et al. } \\
\text { (2018) }\end{array}$ & $\begin{array}{c}\text { Dagvadorj } \\
\text { et al. } \\
(\mathbf{2 0 1 8})\end{array}$ & $\begin{array}{c}\text { Kim et } \\
\text { al. } \\
(2019)\end{array}$ & $\begin{array}{c}\text { Mirzakhani } \\
\text { et al. } \\
(2007)\end{array}$ & $\begin{array}{c}\text { Hochstedler } \\
\text { et al. } \\
(2020) \\
\end{array}$ \\
\hline $\begin{array}{l}\text { Does this research address clearly focused } \\
\text { issues? }\end{array}$ & 1 & 1 & 1 & 1 & 1 & 1 & 1 & 1 \\
\hline $\begin{array}{l}\text { Was the group included in an acceptable } \\
\text { way? }\end{array}$ & 1 & 1 & 1 & 1 & 1 & 1 & 1 & 1 \\
\hline $\begin{array}{l}\text { Is exposure measured accurately to minimize } \\
\text { bias? }\end{array}$ & 1 & 1 & 1 & 1 & 1 & 1 & 1 & 1 \\
\hline $\begin{array}{l}\text { Are the results measured accurately to } \\
\text { minimize bias? }\end{array}$ & 1 & 1 & 1 & 1 & 1 & 1 & 1 & 1 \\
\hline $\begin{array}{l}\text { Have the authors identified all the important } \\
\text { confounding factors? }\end{array}$ & 1 & 1 & 1 & o & 1 & 1 & 1 & 1 \\
\hline $\begin{array}{l}\text { Was the follow-up to the subject of this study } \\
\text { complete? }\end{array}$ & 1 & 1 & 1 & 1 & $\mathrm{O}$ & 1 & $\mathrm{O}$ & 1 \\
\hline What are the results of this study? & 1 & $\mathrm{O}$ & 1 & o & 1 & 1 & 1 & 1 \\
\hline How precise is the result? & 1 & 1 & 1 & 1 & 1 & 1 & 1 & 1 \\
\hline Do you believe in the results? & 1 & 1 & 1 & 1 & 1 & 1 & 1 & 1 \\
\hline $\begin{array}{l}\text { Can the results be applied to the local } \\
\text { population? }\end{array}$ & 1 & 1 & 1 & 1 & 1 & 1 & 1 & 1 \\
\hline $\begin{array}{l}\text { Are the results of this study consistent with } \\
\text { other available evidence? }\end{array}$ & 1 & 1 & 1 & 1 & 1 & 1 & 1 & 1 \\
\hline $\begin{array}{l}\text { What are the implications of this study for } \\
\text { practice? }\end{array}$ & 1 & 1 & 1 & 1 & 1 & 1 & 1 & 1 \\
\hline Total & 12 & 11 & 12 & 10 & 11 & 12 & 11 & 12 \\
\hline
\end{tabular}

Note: Yes $=1$, No $=0$ 
Table 2. Descriptions of primary studies included in the meta-analysis

\begin{tabular}{|c|c|c|c|c|c|c|c|c|}
\hline $\begin{array}{c}\text { Author } \\
\text { (year) }\end{array}$ & Title & Country & $\begin{array}{c}\text { Study } \\
\text { Design }\end{array}$ & Sample & $\begin{array}{c}\mathbf{P} \\
\text { Population } \\
\end{array}$ & $\begin{array}{c}\text { I } \\
\text { Intervention } \\
\end{array}$ & $\begin{array}{c}\mathrm{C} \\
\text { Comparison } \\
\end{array}$ & $\begin{array}{c}\text { O } \\
\text { Outcome } \\
\end{array}$ \\
\hline $\begin{array}{l}\text { Kirkegaard } \\
\text { et al. } \\
(2006)\end{array}$ & $\begin{array}{l}\text { Gestational age } \\
\text { and birth weight } \\
\text { in relation to } \\
\text { school per- } \\
\text { formance of 10- } \\
\text { year-old } \\
\text { children: A } \\
\text { follow-up study } \\
\text { of children born } \\
\text { after } 32 \\
\text { completed } \\
\text { weeks }\end{array}$ & Denmark & Cohort & 5,319 & $\begin{array}{l}\text { Children } 2 \\
\text { years old }\end{array}$ & $\begin{array}{l}\text { Gender, age of pregnant } \\
\text { women, mother's education, } \\
\text { father's educators, children } \\
\text { living with parents, breastfeed- } \\
\text { ing, mothers smoking and con- } \\
\text { suming alcohol and caffeine } \\
\text { during pregnancy, gestational } \\
\text { age and birth weight }\end{array}$ & $\begin{array}{l}\text { Not given ASI, } \\
\text { normal birth, } \\
\text { normal birth } \\
\text { weight }\end{array}$ & $\begin{array}{l}\text { School } \\
\text { performance } \\
\text { (Difficulty } \\
\text { reading, } \\
\text { spelling, and } \\
\text { arithmetic) }\end{array}$ \\
\hline $\begin{array}{l}\text { Amin et al. } \\
(2007)\end{array}$ & $\begin{array}{l}\text { Hyperbilirubine } \\
\text { mia and } \\
\text { language delay } \\
\text { in premature } \\
\text { infants }\end{array}$ & Canada & Cohort & 125 & $\begin{array}{l}9 \text { month old } \\
\text { child }\end{array}$ & $\begin{array}{l}\text { Gestational age, birth weight, } \\
\text { gender, race, mother's educa- } \\
\text { tion, exposure to illegal drugs, } \\
\text { mode of delivery, Apgar score }\end{array}$ & $\begin{array}{l}\text { Normal birth } \\
\text { weight, not } \\
\text { exposed to } \\
\text { drugs, normal } \\
\text { birth }\end{array}$ & $\begin{array}{l}\text { Language } \\
\text { Delay }\end{array}$ \\
\hline $\begin{array}{l}\text { Udo et al. } \\
(2016)\end{array}$ & $\begin{array}{l}\text { Maternal inti- } \\
\text { mate partner } \\
\text { violence: } \\
\text { Relationships } \\
\text { with language } \\
\text { and neurological } \\
\text { development of } \\
\text { infant and } \\
\text { toddlers }\end{array}$ & USA & Cohort & 210 & $\begin{array}{l}\text { Children } \\
\text { aged } 9 \text { to } 11 \\
\text { years }\end{array}$ & $\begin{array}{l}\text { Race, age of pregnant women, } \\
\text { mother's education, father's } \\
\text { education, parental employ- } \\
\text { ment status, smoking before } \\
\text { pregnancy, smoking during } \\
\text { pregnancy, depression, stress, } \\
\text { encouragement from peers and } \\
\text { others, birth, birth weight }\end{array}$ & $\begin{array}{l}\text { No smoking } \\
\text { before and } \\
\text { during preg- } \\
\text { nancy, no } \\
\text { depression or } \\
\text { stress, normal } \\
\text { birth, normal } \\
\text { birth weight }\end{array}$ & $\begin{array}{l}\text { Language } \\
\text { Delay }\end{array}$ \\
\hline $\begin{array}{l}\text { Taylor et al. } \\
(2018)\end{array}$ & $\begin{array}{l}\text { Prenatal and } \\
\text { perinatal risks } \\
\text { for late language } \\
\text { emergence in a } \\
\text { population-level } \\
\text { sample of twins } \\
\text { at age } 2\end{array}$ & Australia & Cohort & 946 & $\begin{array}{l}\text { Children } \\
\text { aged } 3 \text { years }\end{array}$ & $\begin{array}{l}\text { Pregnant mother's age, } \\
\text { mother's education, marital } \\
\text { status, income, socio-economic } \\
\text { status, Apgar score, gestational } \\
\text { age }\end{array}$ & $\begin{array}{l}\text { The baby is born } \\
\text { normal }\end{array}$ & $\begin{array}{l}\text { Language } \\
\text { Delay }\end{array}$ \\
\hline
\end{tabular}




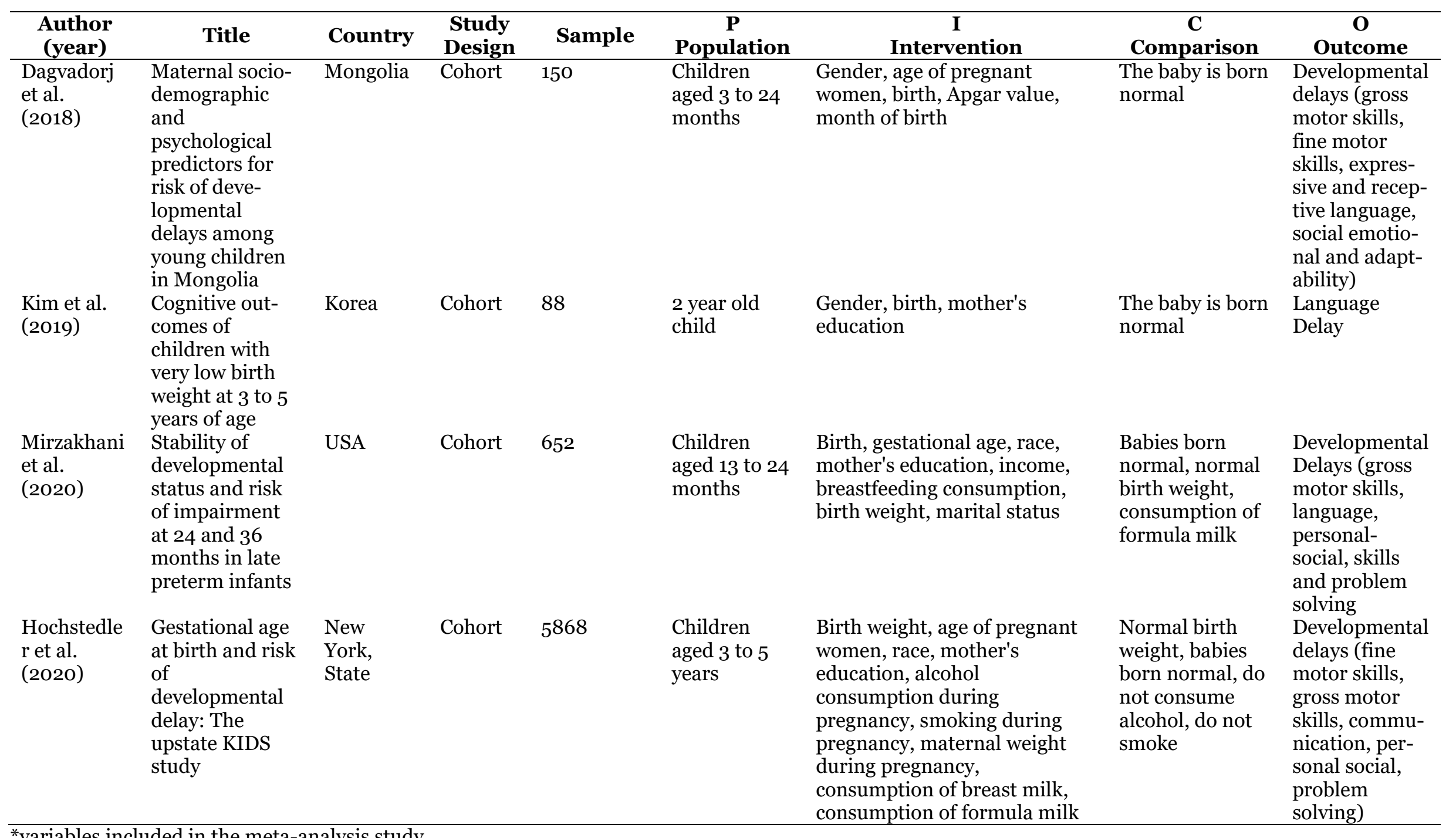




\section{DISCUSSION}

This study is a systematic study and metaanalysis that takes the theme of preterm babies with language delay in children. This study discusses data about language delay because language is an important developmental component and is one of the main milestones in child development.

This systematic study study and metaanalysis used research that controlled for confounding factors which could be seen from the study inclusion requirements, namely multivariate analysis and the statistical result reported was the adjusted odd ratio (aOR).

Estimates of the combined effect of preterm infants on language delay in children were processed using the RevMan 5.3 application with the generic inverse variance method. The results of the systematic study and meta-analysis are presented in the form of a forest plot and a funnel plot. Forest plots provide an overview of information from each of the studies examined in the meta-analysis, and estimates of the overall results (Murti, 2018).

The funnel plot shows visually the amount of variation (heterogeneity) (Akobeng, 2005 in Murti, 2018). The funnel plot shows the relationship between the effect size of the study and the sample size of the various studies studied, which can be measured in a number of different ways (Murti, 2018).

\section{The effect of preterm babies on language delay}

There are 8 observational research articles with a cohort study design as a source of meta-analysis of the effect of preterm infants on language delay in children.

The results of the meta-analysis of the cohort study showed that preterm infants could cause language delay in children 1.65 times as much as those who were born nominally $(\mathrm{aOR}=1.65,95 \% \mathrm{CI}=1.11$ to 2.44, $\mathrm{p}=0.010$ ).

This is supported by Viana et al (2013), which concluded that there is a significant relationship between chronological age and age of cognitive and language development. Cattani et al (2010) added that premature children showed delays in all three aspects of communication and language. In particular, communicative-linguistic age tends to lag about 3 months behind chronological age when children are between 12 and 24 months old.

Babies born $<37$ weeks and the risk of health problems faced by premature babies increase the risk of developmental and academic disabilities. The risk of disorders will increase in babies born at a younger gestational age (Mann, 2011).

Babies born prematurely have problems with brain development and emotional development. Some of the risks of growth and development disorders for premature babies, namely: hearing and vision, language skills, psychomotor and behavior, cognitive abilities, and emotional development. The unique human ability to acquire language is a result of the functioning of the nervous system. Imperfections in the nervous system will affect a person's language skills. This disorder is very complex in terms of cognitive, communication, social interaction, attraction, and children's imagination activities, as well as children's emotions (Endarwati, 2015).

\section{AUTHOR CONTRIBUTION}

Alfiani is the main researcher who selects the topic, explores and collects research data. Didik Gunawan Tamtomo and Bhisma Murti played a role in analyzing data and reviewing research documents.

\section{CONFLICT OF INTEREST}

There is no conflict of interest in this study. 
Sutanto et al./ The Effect of Premature Births on Language Delay in Children

\section{FUNDING AND SPONSORSHIP}

This study is self-funded.

\section{ACKNOWLEDGEMENT}

We are very grateful to the database providers PubMed, Wiley, Springer Link, Elsevier, BMC Pediatrics and Google Scholar.

\section{REFERENCE}

Cattani A, Bonifacio S, Fertzs M, Iverson JM, Zocconi E, Caselli MC (2010). Communicative and linguistic development in preterm children: a longitudinal study from 12 to 24 months. Int J Lang Comm Dis. 45(2):162-73. https://doi.org/10.3109/1368282090 2818870.

Dagvadorj A, Ganbaatar D, Balogun OO, Yonemoto N, Bavuusuren B, Takehara K, Mori R, Akahira-Azuma M (2018). Maternal socio-demographic and psychological predictors for risk of developmental delays among young children in Mongolia. BMC Pediatr 18, 68 (2018). https://doi.org/10.1186/s12887-018-1017-y.

Eisenberg, N, Ivanna K Guthrie, Amanda Cumberland, Bridget C Murphy, Stephanie A Shepard, Qing Zhou, Gustavo Carlo (2002). Prosocial development in early adulthood: A longitudinal study. J Pers Soc Psychol. 82(6): 9931005. https://pubmed.ncbi.nlm.nih.gov/12051585/.

Endarwati O (2015). Cacat sintaksis keluaran wicara pada anak penyandang autis di SD Lab PGSD Setia Budi dan SDIT Al-Mubarak Rawasari (Suatu kajian neurolinguistik). (Syntax defects of speech output in children with autism in Setia Budi's PGSD Lab Elementary School and SDIT AlMubarak Rawasari (A Neurolinguistic Study)). Jurnal Atkhais. 6(1). https://doi.org/10.21009/ARKHAIS.061.05.
Mann D (2011). Study developmental delay for late preterm babies. Available at: https://www.webmd.com/baby/news /20110531/studydevelopmentaldelays-for-late-preerm-babies.

Mariyana R (2018). Hubungan riwayat prematur dengan tumbuh kembang anak usia 1 tahun. (Relationship between premature history and development and development of 1 year old children). J Hum Resour. 3(3): 183-188.

Murti B (2018). Prinsip dan Metode Riset Epidemiologi (Epidemiological Research Principles and Methods). Edisi ke 5. Surakarta: Program Studi Ilmu Kesehatan Masyarakat.

Patterson JL, Dale PS (2017). Language development and literacy: Early identification of language delay. Encyclopedia on Early Childhood Development. [Article]. Available from: http://www.child-encyclopedia.com/sites/default/files/textes-experts/en/622/early-identification-of-language-delay.pdf.

Putri AK, Mawarni H, Yara NY, Sumarlam (2018). Kemampuan berbahasa anak lahir prematur usia dua tahun: Kajian Psikolinguistik. (Language ability of children born premature at two years old: psycholinguistic study). Jurnal Arkhais. 9(1): 58-71. https://doi.org/10.21009/ARKHAIS.091.

Putri AR, Pamungkasari EP, Prasetya $\mathrm{H}$ (2020). Factor affecting early detection and stimulation by mothers and their impact on receptive language skill of children age 4 to 6 years. J Matern Child Health. 5(3). 235-242. https://doi.org/10.26911/thejmch.20 20.05.03.02.

Raybaud C, Ahmad T, Rastegar N, Shroff $M, A l$ Nassar M (2013). The premature brain: Developmental and lesional anatomy. Neuroradiology. 55(2): 
Sutanto et al./ The Effect of Premature Births on Language Delay in Children

23-40. https://doi.org/10.1007/soo234-013-1231-0.

Soubasi V, Velikos K, Michalettou I, Papadopoulou V, Sarafidis K, Nakas C, Drossou-Agakidou V (2014). Longitudinal development of language skills in premature infants using bayley scales of infant development. Arch Dis Child. Doi: http://dx.doi.org/10.1136/archdischild-2014-307384.1037s.

Sulistiarini D, Berliana SM (2016). Faktorfaktor yang Mempengaruhi Kelahiran Prematur di Indonesia: Analisis Data RISKESDES 2013 (Factors Affecting Preterm Birth in Indonesia: Analysis of the 2013 RISKESDES Data). EJournal WIDYA Kesehatan dan Lingkungan. 1(2).
Viana TP, Andrade ISN, Lopes ANM (2014). Cognitive and language development in preterm infants. J Paediatr Child Health. 19(1): 1-6. https://doi.org/10.159o/S2317-64312014000100002.

WHO (2012). Born too soon: The global action report on preterm birth. Geneva: WHO.

WHO (2018). The life-course approach: from theory to practice. Case stories from two small countries in Europe. WHO Regional Offce for Europe: UN City, Marmorvej.

WHO (2015). Preterm Birth. Http://www.who.int/mediacentre/factsheets/fs36 3/en/ Diakses: 18 Januari 2015. 